\title{
PRODUCTION OF ALKALINE PROTEASE ENZYME FROM BACILLUS SUBTILIS 168 ISOLATED FROM SOIL SAMPLES COLLECTED FROM A DAIRY FARM
}

\author{
Anitha, D. and A. Kumaraswamy* \\ P.G. and Research Centre, Department of Zoology, S.T. Hindu College, Nagercoil 629 002, \\ Kanyakumari District, Tamil Nadu, India. \\ *Email: surejkensa@gmail.com
}

\begin{abstract}
Screening and isolation of protease producing strains of bacteria were carried out from a dairy farm located in Nagarcoil, Tamilnadu.The isolates were positive on skim milk agar (1\%) and thus are selected as protease producing strain. The organisms were tested for various biochemical tests, which lead to their identification as Bacillus subtilis producing protease enzyme. These Bacillus subtilis could group up to $40^{\circ} \mathrm{C}$ and $\mathrm{pH}$ range 6-9 with optimal growth temperature and $\mathrm{pH}$ at $37^{\circ} \mathrm{C}$ and 8.0 respectively. It was also optimized for carbon test and nitrogen test with optimal growth in dextrose and peptone respectively. Enzyme production was carried in 1 litre of optimized media in the fermenter at $37^{\circ} \mathrm{C}$ for 48 hours at pH 8.0. This result showed that Bacillus subtilis under study is a good producer of extra cellular protease, which can be beneficial for industries.
\end{abstract}

Keywords: Bacillus subtilis, cellular protease, identification.

\section{INTRODUCTION}

Proteases, one among the three largest groups of industrial enzymes, accounts for about $60 \%$ of the total worldwide sale of enzymes from biological sources sincethey possess almost all characteristics desired for their biotechnological applications (Adinarayanaet al., 2003). Proteases constitute a class of industrial enzymes, which alone form approximately $60 \%$ of the total world-wide enzyme production (Chu 2007). Among the various proteases, microbial proteases play an important role in biotechnological processes. Alkaline proteases produced are of special interest as they could be used in manufacture of detergents, food, pharmaceuticals and leather (Saeki et al., 2007, Dias et al., 2008). In recent years a number of studies have been conducted to characterize alkaline protease from different microorganisms. However, many of the alkaline proteases applied to industrial purposes face some limitations such as low stability towards surfactants and production cost of the enzymes arisen from growth medium(Joo and Chang,2005). Using of costeffective growth medium for the production ofalkaline proteases from an alkalophilicBacillus sp. is especially important (Jooet al. 2002). Therefore, there is a need to the search of new strains of bacteria that produce proteolytic enzymes with novel properties andthe development of low cost media.

\section{MATERIALS AND METHODS}

\subsection{Collection of samples}

Protease producing organisms were isolated from soil samples collected from a dairy farm located in Nagarcoil, Tamilnadu. Samples were serially diluted using distilled water and spread plated on the surface of casein agar plates (nutrient agar with $1 \%$ casein) and incubated at $30^{\circ} \mathrm{C}$ for $48 \mathrm{hrs}$ (Naidu and Devi, 2005).

\subsection{Screening of protease producers}

The collected samples were seriallydiluted and streaked on skin milk agarplates. The plates were incubated for 48hat $37 \mathrm{C}$ and protease producers wereselected by observation of zone ofhydrolysis around the colonies (Genkalet al., 2006).

\subsection{Characterization of protease enzyme}

The total protein contents of the sampleswere determined according to the method described by Lowry s method usingBovine Serum Albumin (BSA) asstandard. Enzyme activity was determinedusing culture supernatant collected bycentrifuging culture broth at 10,000 rpmfor $15 \mathrm{~min}$. Protease activity was measuredby standard assay procedure proposed byAkcan and Uyar, 2011. About $0.5 \mathrm{ml}$ of $0.5 \%$ casein and $1.25 \mathrm{ml}$ of tris buffer (pH-8.0 to 14.0) was added into $0.2 \mathrm{ml}$ of eachof the culture supernatant separately. Mixture was 
incubated for $30 \mathrm{~min}$ at 370C.About $3 \mathrm{ml}$ of trichloroacetic acid wasadded and incubated at 400C for $10 \mathrm{~min}$ toform precipitate. The mixture wascentrifuged at $10,000 \mathrm{rpm}$ for $15 \mathrm{~min}$ and $0.5 \mathrm{ml}$ of supernatant was collected.

Reagent containing sodium carbonate, copper sulphate, sodium potassiumtartarate was mixedwith $1 \mathrm{ml}$ of Folinphenolreagent. The mixture wasincubated at dark for 30 minutes to formblue colour. The absorbance was read at660 $\mathrm{nm}$ to determine the optical density ofeach sample. The obtained OD wasextrapolated in the standard graph. Thestandard curve was obtained for series ofknown concentrations of bovine serumalbumin. From the graph, the amount ofprotein liberated due to the action ofenzyme protease in the supernatant wasdetermined. One unit of protease activitywas defined as the amount of enzymerequired to liberate $1 \mathrm{~g} / \mathrm{ml}$ tyrosine underthe experimental conditions.Enzyme activity $=O D$ value $X$ amount ofprotein released (g)/ concentration ofsubstrate $X$ time of incubation $\mathrm{X}$ weight ofthe sample.

\subsection{Optimization of conditions for enhancedenzyme production (Das and Prasad, 2010)}

Standard methods were adopted tooptimize the parameters like culturalconditions, carbon, nitrogen, temperature, $\mathrm{pH}$, inoculum size and substrates.

\subsection{Mass production of alkaline protease}

The fermentation was carried out in asterile Stirred Bed Reactor (SBR). Thevessel was maintained at optimizedtemperature, $\mathrm{pH}$ and other \& incubated for $48 \mathrm{~h}$ in a shaking incubator. At the end offermentation period, the whole cultureboth was centrifuged at $10,000 \mathrm{rpm}$ for 15 minutes, to remove the cellular debris andthe clear supernatant was used for enzymeanalysis.

\subsection{Characterization of partially purifiedalkaline protease}

The culture filtrate (crude protease) wascollected aseptically after upstream production in a SBR under controlled conditions. The required volume of the spent media was centrifuged at 10,000 rpmfor $15 \mathrm{~min}$ at $4^{\circ} \mathrm{C}$ in order to obtain a cell free filtrate. About $200 \mathrm{ml}$ of the cell free filtrate containing protease were collected and their proteolytic activity was determined. Protease enzyme was purified by ammonium sulfate fractionation the concentration of ammonium sulphate required for precipitation varies fromprotein to protein and should bedetermined empirically. The two milliliter of the crude protease enzyme was first brought to $20 \%$ (w/v) saturation with solid ammonium sulfate (enzyme grade) and $100 \%$ saturated dialysis against distilledwater in a dialysis bag (cut off 30 ) for $3 \mathrm{~h}$, followed by dialysis against phosphatebuffer at $\mathrm{pH}$ 7.0. The obtained proteaseenzyme preparation was concentrated against crystals of sucrose and kept in there frigerator at $4^{\circ} \mathrm{C}$. The enzyme activityand protein content was determined forsalted out dialyzed enzyme fractions. Theenzyme activity of the purified fractions ofthe alkaline protease after harvesting, ammonium sulfate precipitation anddialysis was determined by the method of Gomori (1955). Separation and sizedetermination of enzyme was performedby SDS-PAGE (Joo et al., 2002).

\section{RESULTS AND DISCUSSION}

\subsection{Density of protease producers}

In the present study soil samples collected from a dairy farm located in Nagercoil were plated on casein agar medium and the microbial density was found to be in the range of $3.22 \times 10^{3}$ to $1.6 \times 10^{4}$ CFU/g(Fig. 1).

\subsection{Screening for proteolytic activity}

From casein agar plates 151 strains of varying morphology were selected and screened for proteolytic activity adopting well assay method. The zone of clearance was measured and found to be in the range of $4 \mathrm{~mm}-15 \mathrm{~mm}$. As most of the strains showed activity with $4 \mathrm{~mm}$ range, 5 potential strains alone were selected for the further study. Among the five, the one with $15 \mathrm{~mm}$ of zone was selected for protease production (Fig.3).

\subsection{Identification of strains}

The potential strains were identified using biochemical methods according to Bergy's manual of determinative bacteriology and identified as $B$. cereus, E. coli, B. subtilis, B. pumilisand P. aeruginosa and were designated with their strain number as $B$. cereus DF 101, E. coli DF 52, B. subtilis DF 49,P. aeruginosa DF 11and B. pumilisDF 78.

\subsection{Inoculum concentration}

When the log phase culture of B. cereus DF 101 was tested for the suitable inoculum concentration in the range of $0.5-3 \%, 1 \%$ inoculum resulted in the maximum OD value of 1.202 . On further increase in concentration of inoculum decrease in growth of the culture in shake flask was noted. Likewise the protease production also found to be the maximum at this inoculum concentration 
(1284U $/ \mathrm{ml} / \mathrm{min}$.). Surprisingly at $3 \%$ inoculum concentration growth was reduced to $0.88 \mathrm{OD}$ at which enzyme production was found to be only $4 \mathrm{U} / \mathrm{ml} / \mathrm{min}$. (Fig. 4 and 5).

\subsection{Static and shaking conditions}

The effect of agitation was tested at the range of $50-200 \mathrm{rpm}$. At 50rpm the OD value was found to be 0.6 which was in increasing trend on further increase up to $150 \mathrm{rpm}$, where OD value of 1.202 was observed. Further increase in agitation reduced the growth and value of enzyme activity (i.e) 0.89 and $800 \mathrm{U} / \mathrm{ml} / \mathrm{min}$. observed at $200 \mathrm{rpm}$. However least growth and enzyme activity were found when incubation was done in static condition. When cultures were kept static growth attained the level of 0.332 OD, which resulted in only 250 $\mathrm{U} / \mathrm{ml} / \mathrm{min}$. of enzyme activity (Fig. 6 and 7).

\section{6. $p H$}

When a $\mathrm{pH}$ range of $\mathrm{pH} 6$ to $\mathrm{pH} 11$ was tested pH 10 resulted in higher OD as well as higher enzyme activity. A maximum of $1249 \mathrm{U} / \mathrm{ml} / \mathrm{min}$. was observed at $\mathrm{pH} 10$ at 36 hrswhere it was 802 $\mathrm{U} / \mathrm{ml} / \mathrm{min}$. at $\mathrm{pH} 8,1031 \mathrm{U} / \mathrm{ml} / \mathrm{min}$. at $\mathrm{pH} 9$ and 981 $\mathrm{U} / \mathrm{ml} / \mathrm{min}$. at $\mathrm{pH} 11$. However it was only 561 $\mathrm{U} / \mathrm{ml} / \mathrm{min}$. at pH 7 at $36 \mathrm{hrs}$. of incubation (Fig. 8 and 9).

\subsection{Temperature}

At $35^{\circ} \mathrm{C}$ maximum $\mathrm{OD}$ value of 1.05 was obtained in which the protease activity observed was $1057 / \mathrm{ml} / \mathrm{min}$. At the end of $42 \mathrm{hrs}$ protease production reduced and the activity was found to be $997 \mathrm{U} / \mathrm{ml} \mathrm{min}$. with a growth of 0.95 OD. Lower growth and enzyme activity were observed at both extremes (i.e.) $25^{\circ} \mathrm{C}$ and $45^{\circ} \mathrm{C}$ (Fig. 10 and 11).

\subsection{NaCl concentration}

When $\mathrm{NaCl}$ concentration of 0 to $2 \%$ was tested at an interval of $0.5 \%$, the maximum growth and enzyme activity were observed at $0.5 \% \mathrm{NaCl}$. Maximum OD value of 1.14 with an enzyme activity of 1092 was obtained at $36 \mathrm{hrs}$ at that concentration. The minimum was observed at $2 \% \mathrm{NaCl}$ with an OD value of 0.78 at $36 \mathrm{hrs}$, at which only $523 \mathrm{U} / \mathrm{ml} / \mathrm{min}$. of enzyme activity was observed. Irrespective of concentration after 36 hrs both OD value and enzyme production were decreased (Fig. 12 and 13).

\subsection{Carbon sources}

In the present study, to select a potential carbon source, glucose, maltose, fructose, sucrose and starch were incorporated in separate flasks at
$1 \%$ concentration. Among them glucose favoured the maximum growth and protease production respectively with $1.3 \mathrm{OD}$ and $1012 \mathrm{U} / \mathrm{ml} / \mathrm{min}$. The minimum growth (0.8 OD) and enzyme production (587U/ml/min.) were observed when starch was used as the sole carbon source (Fig. 14 and 15).

\subsection{Concentration of carbon source}

The ideal carbon source glucose was tested from $0.5 \%$ to $2.5 \%$ in which $1 \%$ resulted in maximum growth as well as the maximum enzyme activity. At $1 \%$ glucose concentration the OD value was found to be 1.392 at which maximum enzyme activity of $996 \mathrm{U} / \mathrm{ml} / \mathrm{min}$. was noted. At $2.5 \%$ of glucose growth was reduced to 0.98 OD with corresponding enzyme activity of $759 \mathrm{U} / \mathrm{ml} / \mathrm{min}$. (Fig. 16 and 17).

\subsection{Nitrogen sources}

When yeast extract, beef extract and peptone were selected as organic nitrogen sources and ammonium nitrate, ammonium sulphate and potassium nitrate were selected as inorganic nitrogen sources, organic nitrogen sources resulted in more growth as well as enzyme production compared to the inorganic forms. Yeast extract showed a maximum of 1.056 OD of growth and $995 \mathrm{U} / \mathrm{ml} / \mathrm{min}$. of enzyme production, whereas with potassium nitrate a minimum of 0.509 OD and $412 \mathrm{U} / \mathrm{ml} / \mathrm{min}$. of enzyme production were observed (Fig. 18).

\subsection{Concentration of nitrogen source}

The concentration of ideal nitrogen source (i.e.) yeast extract was tested at $0.1-1 \%$ level, $0.5 \%$ favoured the growth of the organism resulting in $1.056 \mathrm{OD}$ at the end of 36 hrsof incubation. At this concentration, the maximum enzyme activity of $878 \mathrm{U} / \mathrm{ml} / \mathrm{min}$. was observed. When yeast extract concentration was further increased, correspondingly enzyme activity decreased, recording the lowest of $522 \mathrm{U} / \mathrm{ml} / \mathrm{min}$. at $1 \%$. Even $0.1 \%$ resulted in slightly higher enzyme activity (579U/ml/min.).

Bacillus species are attractive industrial organisms for a variety of reasons, including their higher growth rates leading to shorter fermentation cycles, their capacity to secrete proteins as extracellular into the medium, and the GRAS (generally regarded as safe) status with the Food and Drug Administration for most of its species, such as B. subtilis, Bacillus licheniformis etc., The present study was on protease production by a $B$. cereus DF 101 strain isolated from a dairy farm soil of 
Nagerkoil District. Microbial proteases are produced from bacteria, fungi and yeast using many processes like solid-state fermentation as well as submerged fermentation (Anwar and Saleemuddin, 1998; Kumar and Takagi, 1999 and Haki and Rakshit, 2003). In the present research work, submerged fermentation technique was used. Even fungi like Aspergillus flavus, A. mellens, A.niger, Chrysosporium keratinophilum, Fusarium graminarum, Pencillium griseofulin, Scedosporium apiosermum etc., were reported to produce protease.

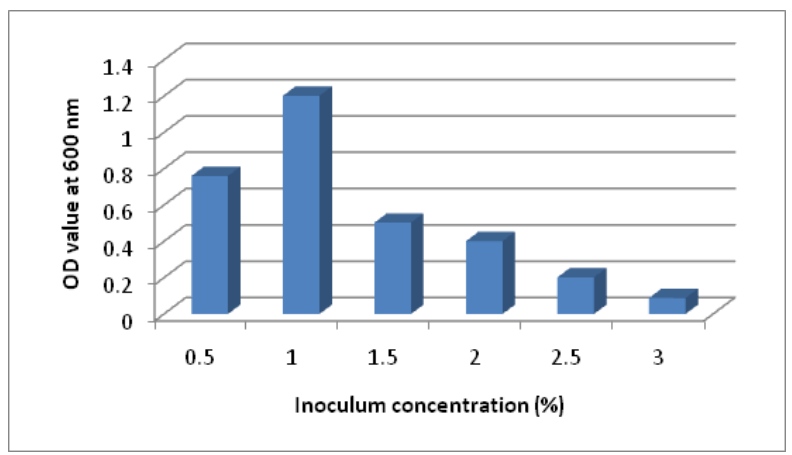

Fig. 1. Effect of inoculum concentration on growth of B.cereus DF 101

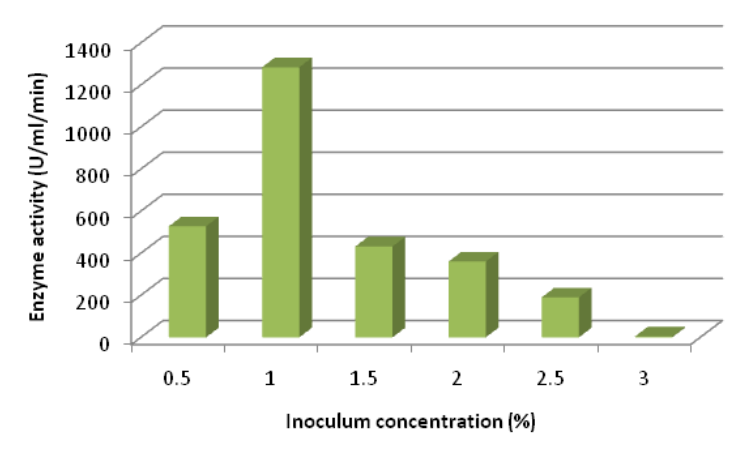

Fig. 2. Effect of inoculum concentration on protease production by B.cereus DF 101

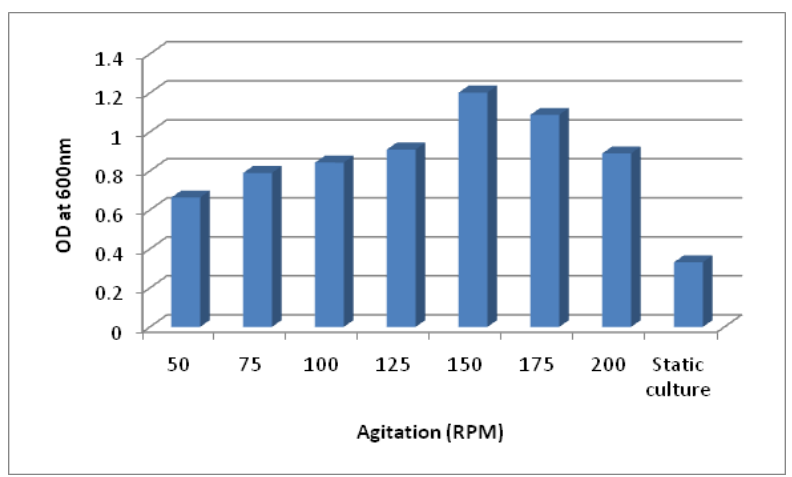

Fig. 3. Effect of agitation on growth of $B$. cereus DF 101

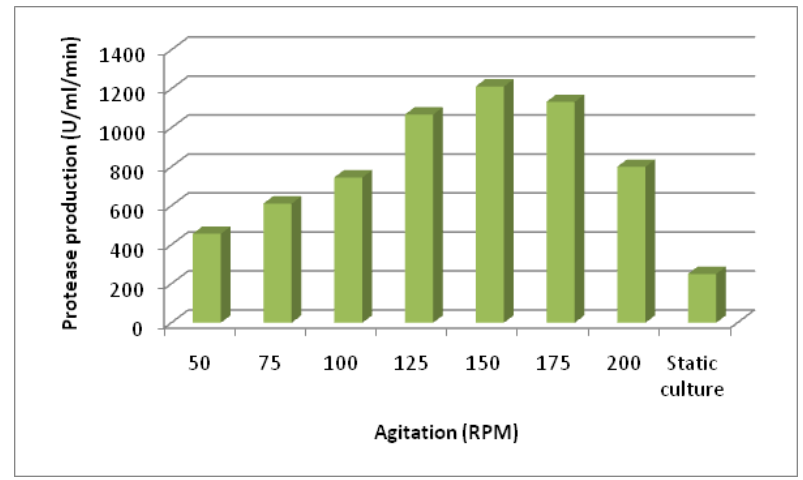

Fig. 4. Effect of agitation on protease production of $B$. cereus DF 101

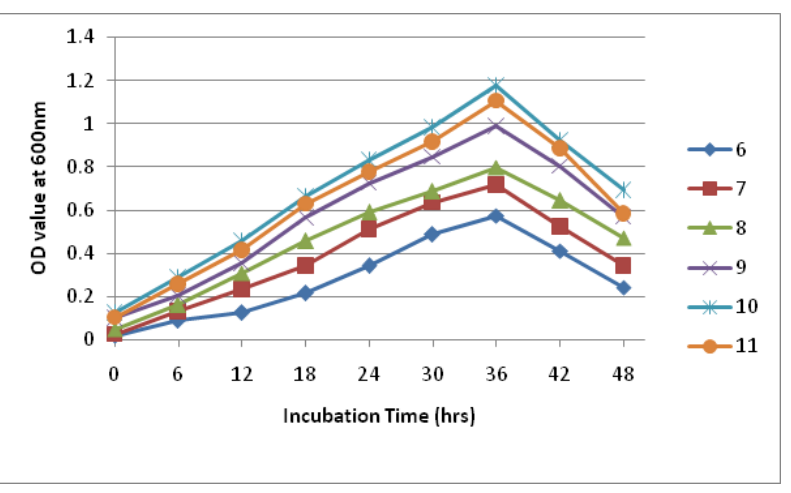

Fig. 5. Effect of pH on growth of B. cereus DF 101

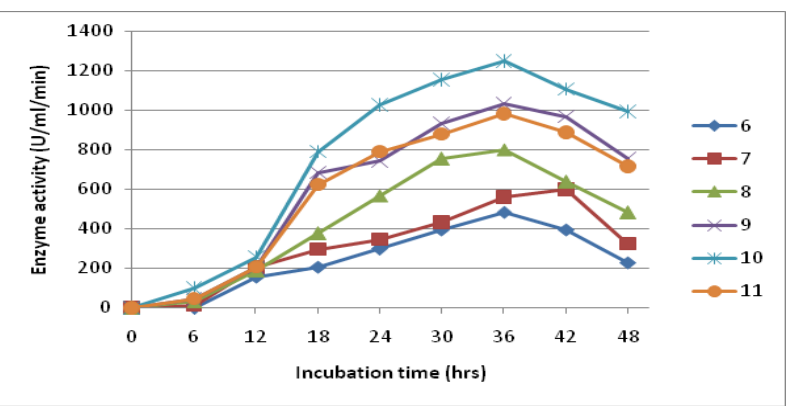

Fig. 6. Effect of $\mathrm{pH}$ on protease production of $B$. cereus DF 101

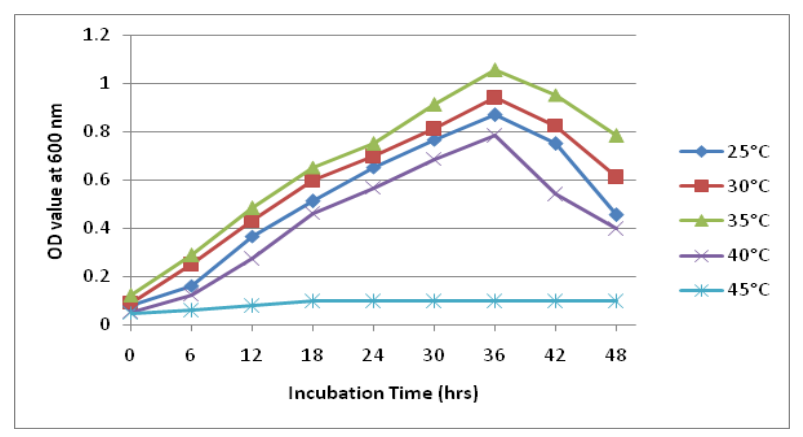

Fig. 7. Effect of temperature on growth of $B$. cereus DF 101 


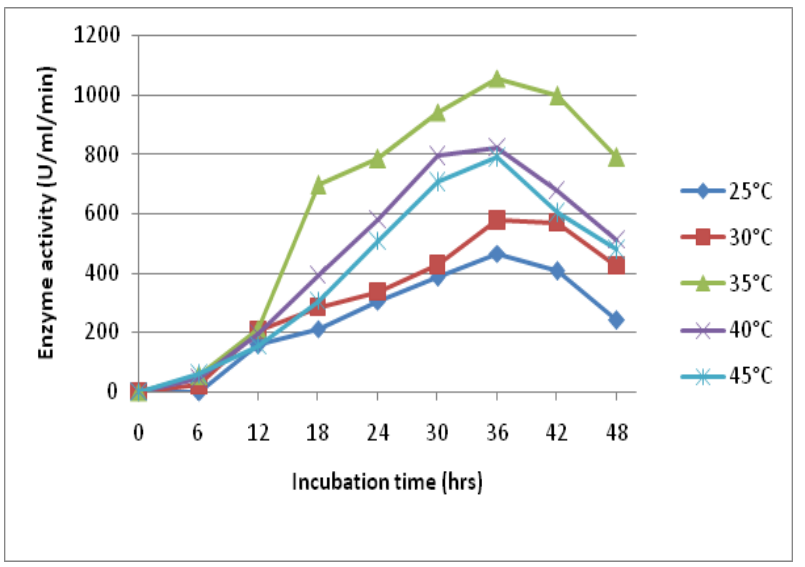

Fig. 8. Effect of temperature on protease production of $B$. cereus DF 101

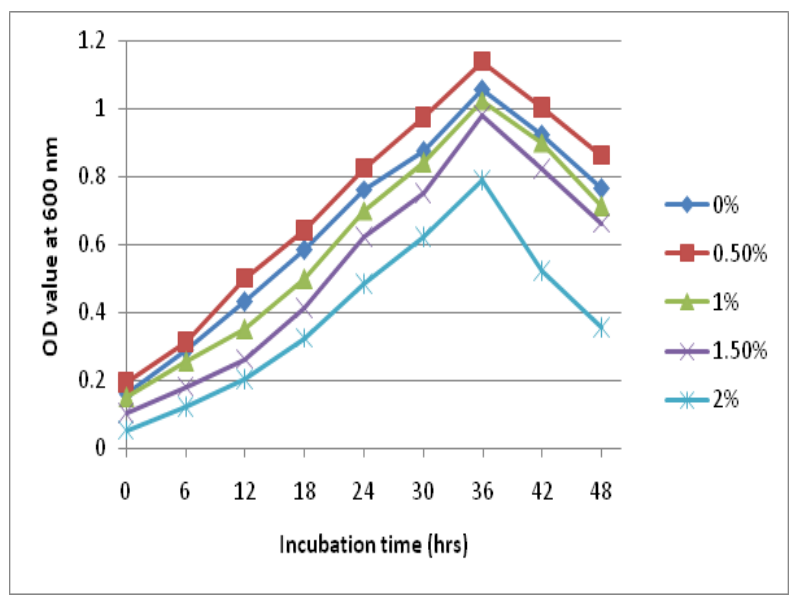

Fig. 9. Effect of $\mathrm{NaCl}$ concentration on growth of B. cereus DF 101

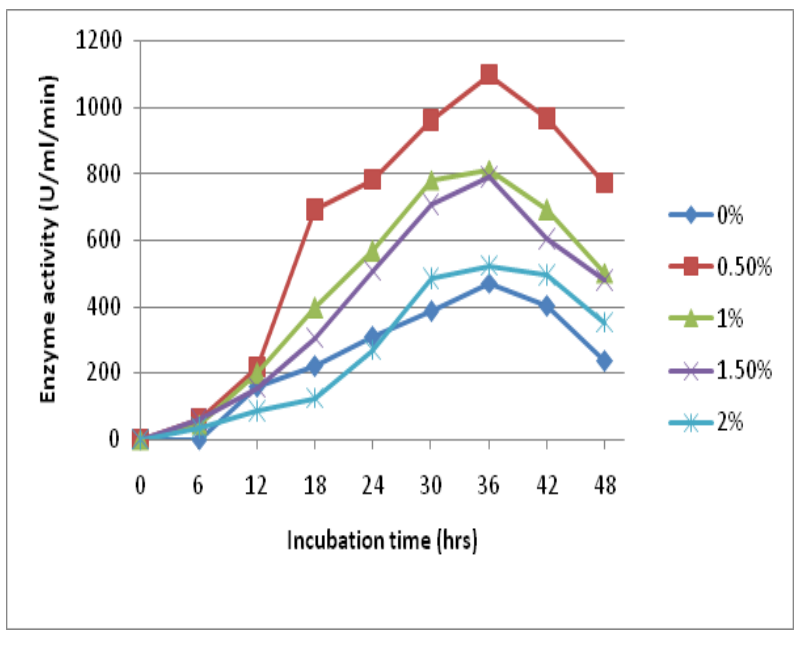

Fig. 10. Effect of $\mathrm{NaCl}$ concentration on protease production of B. cereus DF 101

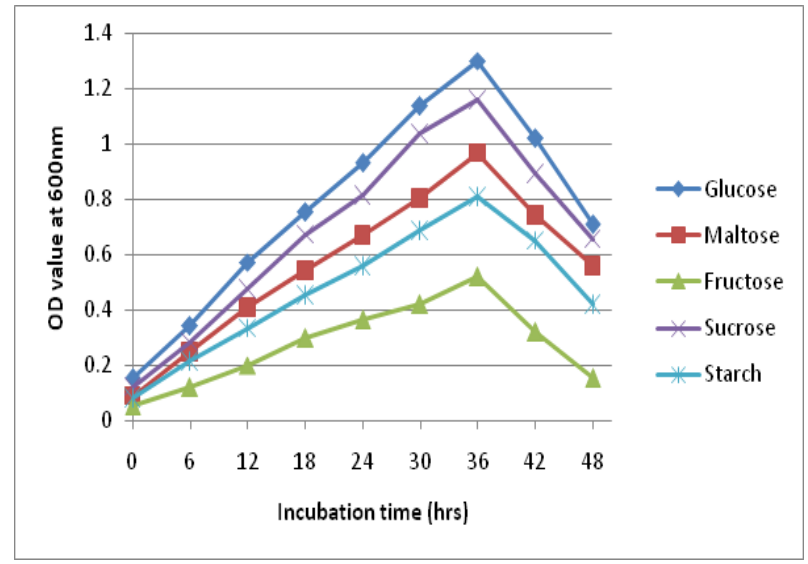

Fig. 11. Effect of carbon source on growth of $B$. cereus DF 101

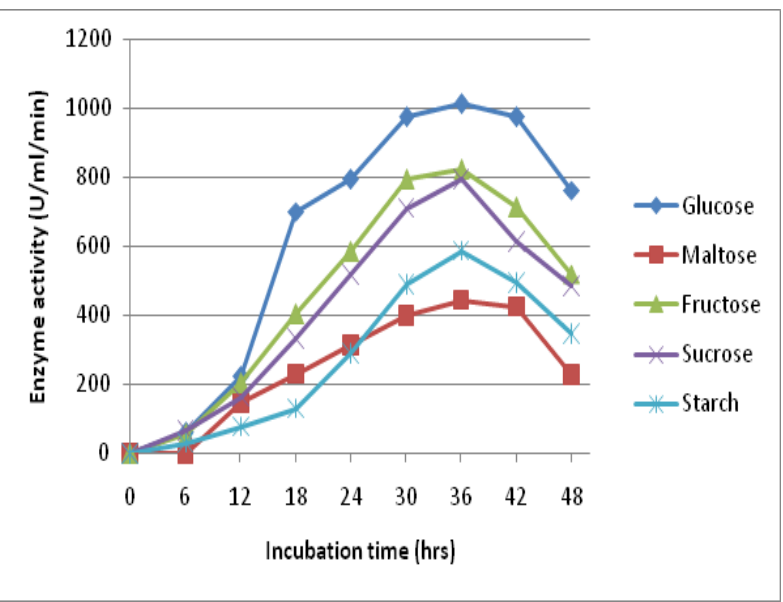

Fig. 12. Effect of carbon source on protease production of B. cereus DF 101

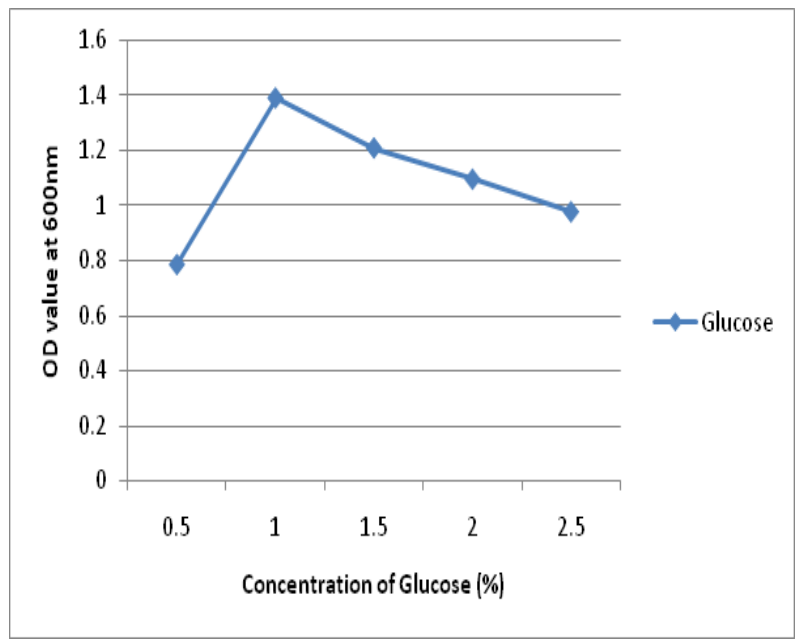

Fig. 13. Effect of glucose concentration on growth of $B$. cereus DF 101at $36 \mathrm{hrs}$ of incubation 


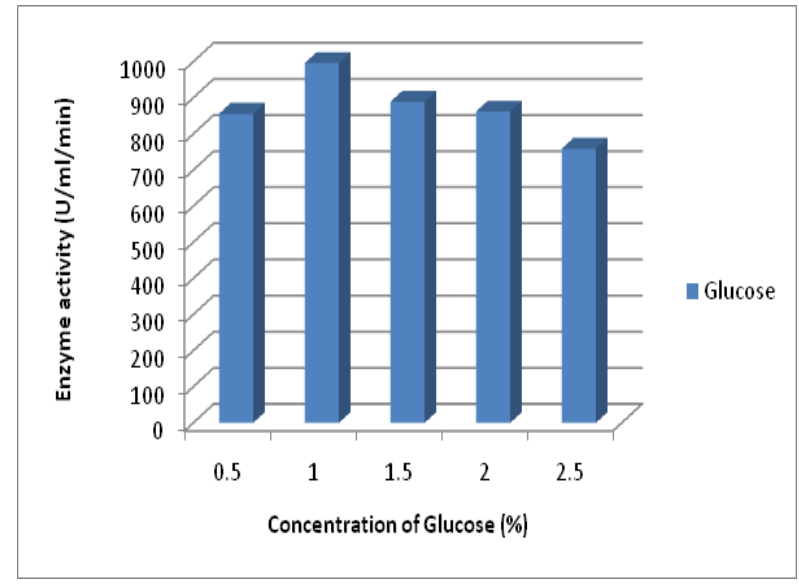

Fig. 14. Effect of glucose concentration on protease production in $B$. cereus DF 101at 36hrs of incubation

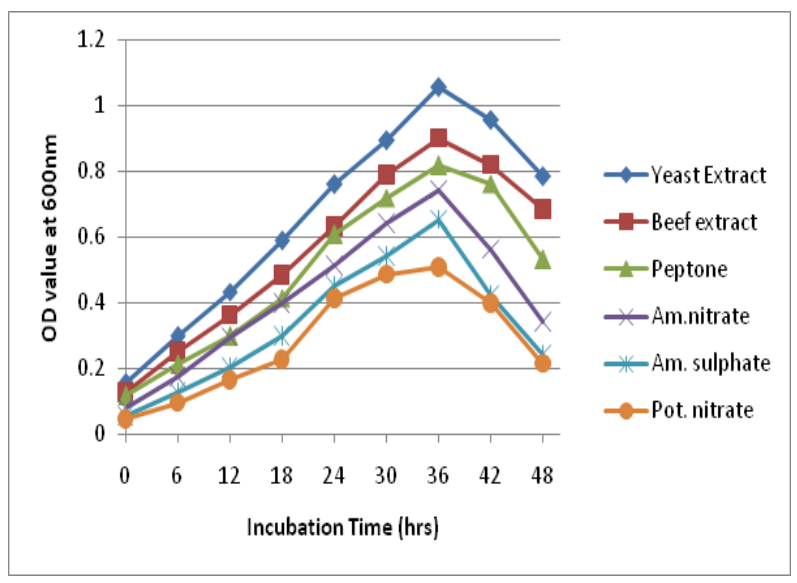

Fig. 15. Effect of nitrogen source on growth of $B$. cereus DF 101

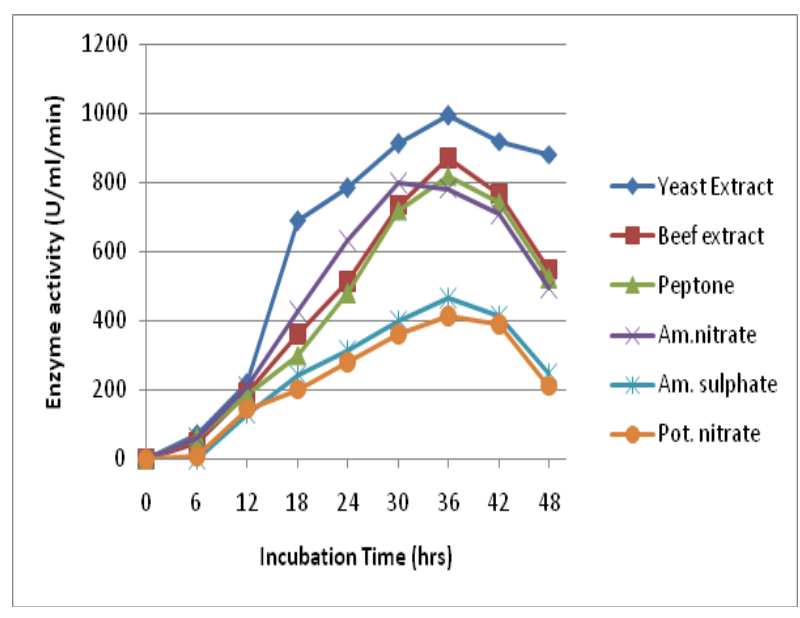

Fig. 16. Effect of nitrogen source on protease production of $B$. cereus DF 101

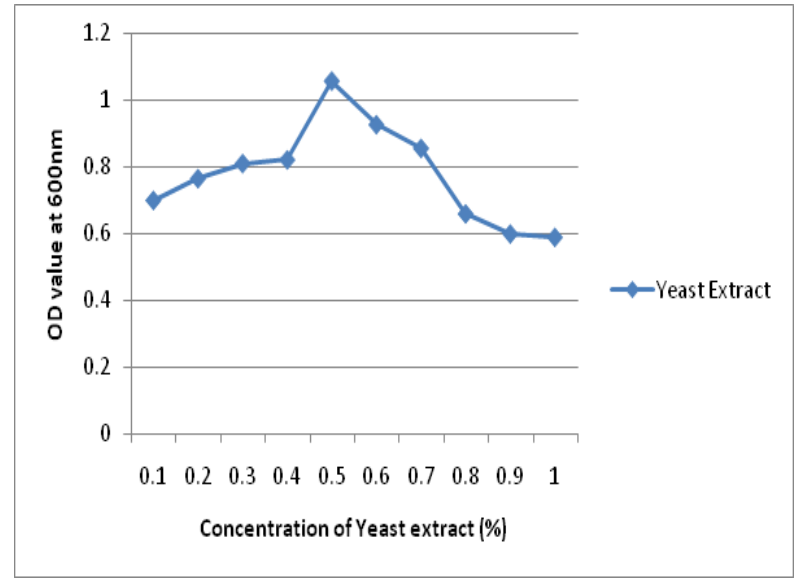

Fig. 17. Effect of yeast extract concentration on growth of $B$. cereus DF 101 at $36 \mathrm{hrs}$ of incubation.

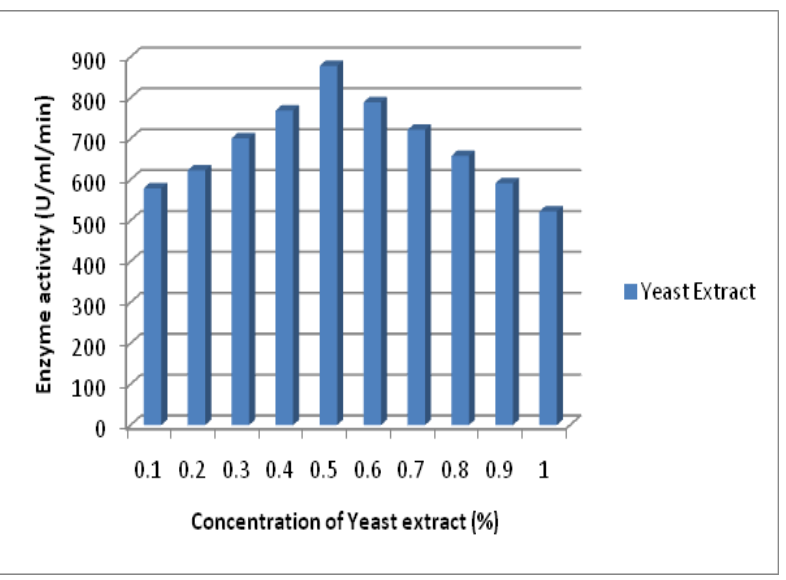

Fig. 18. Effect of yeast extract concentration on protease production in $B$. cereus DF 101at 36hrs of incubation

Bacillus species are considered as major workhorse industrial microorganisms with roles in applied microbiology, which date back more than a thousand years, since the production of natto by solid-state fermentation of soybeans using Bacillus subtilis (natto) which was first practiced in Japan (Hara and Ueda, 1982).

\section{CONCLUSION}

Thus in the present study a dairy farm soil originated B.cereus DF 101 strain was found to be an ideal producer of alkaline protease and the study also revealed the potential for the industrial scale production using this strain. The abundance of protease producers in dairy farm soil sample indicated them as a new source for the search of alkaline proteases. 


\section{REFERENCES}

Adinarayana, K., P. Ellaiah and D. Prasad, (2003). Purification and partial characterization of thermo stable serine alkaline protease from a newly isolated Bacillus subtilis PE-II. AAPS Pharma Sci Tech 4: 440448.

Anwar, A. and M. Saleemuddin, (1998). Alkaline proteases: a review. Bioresour. Technol.64: 175.

Chu, W.H. (2007).Optimization of extracellular alkaline protease production from species of Bacillus. J. Ind. Microbiol. Biotech. 34: 241-245.

Dias, D.R., D.M. Vilela, M.P.C. Silvestre and R.F. Schwan, (2008). Alkaline protease from Bacillus sp. isolated from coffee bean grown on cheese whey. World J. Microbiol. Biotechnol. 24: 20272034.

Haki, G.D. and S.K. Rakshit, (2003). Developments in industrially important thermostable enzymes: a review. Bioresour. Technol. 89: 17.

Hara, T., and S. Ueda, (1982). Regulation of polyglutamate in Bacillus subtilis (natto): transformation of high PGA productivity. Agri.

Biol. Chem. 46: 2275-2281.

Joo, H.S. and C.S. Chang, (2005). Production of protease from a new alkalophilic Bacillus sp. I312 grown on soybean meal: optimization and some properties. Process Biochem. 40: 12631270.

Joo, H.S., C.G. Kumar, G.C. Park, K.T. Kim, S.R. Paik and C.S. Chang, (2002).Optimization of the production of an extracellular alkaline protease from Bacillus horikoshii. Process Biochem. 38: 155-159.

Naidu, K.S.B. and K.L. Devi, (2005).Optimization of thermostable alkaline protease production from species of Bacillus using rice bran. Afr. J. Biotechnol. 4: 724-726.

Saeki, K., K. Ozaki, T. Kobayashi and S. Ito, (2007). Detergent Alkaline Proteases: Enzymatic Properties, Genes, and Crystal Structures. J. Biosci. Bioeng. 6: 501-508. 